\title{
Efficiency of Single Trait Selection for Improving Yield and Earliness in Varietal Maintenance of Giza 90 Egyptian Cotton
}

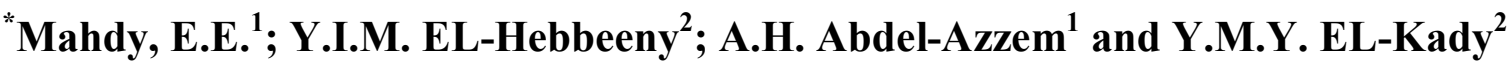

\author{
${ }^{1}$ Assiut Univ. Fac. Agric. \\ ${ }^{2} \mathrm{ARC}$, Cotton Res. Ins. \\ "Corresponding author: ezzatemahdy@yahoo.com
}

Received on: $27 / 7 / 2016$

Accepted for publication on: 1/8/2016

\section{Abstract}

The present study was carried out at Shandaweel Res. Sta. Sohag, Cotton Res. Inst., (ARC), during the three summer seasons of 2013 -2015. The basic materials were selfed seeds of 60 single plants selected from the breeding nursery of renewal and maintenance of Giza 90 (the same materials used for producing the nucleolus of G.90). The main objective of this work was to study the possibility of selection elite high yielding plants characterized by the same fiber properties of Giza 90. To attain this goal, single trait selection for lint yield, lint percentage and earliness was applied for two cycles. Average of the ten selected families indicated that selection for LY/P ranked the first and improved LY/P by $20.30 \%$ of the check strain followed by selection for days to first flower method $(15.82 \%)$, and LY/P restricted by DFF (11.54\%). Generally, single trait selection is an effective method to improve selection criterion. The observed genetic gain indicated that single trait selection resulted in several superior families significant out yielded the check strain and better in one or more of the three main fiber properties; fineness, strength and Upper Half Mean length. Therefore, the official method of maintaining and renewing Egyptian cotton varieties should be modified to allow selection for yield beside preserving fiber properties.

Keywords: Maintenance of Egyptian cotton, single trait selection, observed genetic gain, genotypic and phenotypic variation, heritability.

\section{Introduction}

Cotton is one of the most important fiber crops in the world and Egypt. It is a shrubnative to tropical and subtropical regions around the world, including the Americas, India, and Africa. However, virtually all of the commercial cotton grown worldwide today is grown from the two species Gossypium hirsutum and Gossypiumbarbadense L. Most of Egyptian cotton varieties were produced by pedigree selection. Independent culling levels selection technique can be used to improve several traits simultaneously. Selection de- pends mainly upon genetic variability (Manning 1956, El-Kilany 1976, Abo El-Zahab and El-Kilany 1979, Mahdy $1983 \mathrm{a}$ and b, Lioyed and Bridges 1995, Mahdy et al. 2007, Tang et al. 2009, El-Lawendy and El-Dhan 2012 and Hassaballa et al. 2012). In Egyptian cotton Mustafa et al. (1995) evaluated 41 strains in one location (Trial A) and five locations (Trial B) and reported genetic coefficient of variation for lint yield of $9.40 \%$ for Trial A and $7.48 \%$ for Trial B. Furthermore, high heritability values were recorded in Trial B. Gomaa and Shaheen (1995) noted high estimates 
of heritability for lint yield /plant, seed index and earliness index; respectively. Singh et al. (1995) found genotypic differences for almost all the studied traits. El-Harony (1998) in a selection experiment found that heritability in broad sense ranged from 4.32 for boll weight to $61.96 \%$ for lint percentage. Otherwise, high to moderate broad sense heritability estimates were found for all traits. Mahdy et al. (2001 a and b) noted high genotypic and phenotypic coefficients of variability for most traits in pedigree line and selection with intermating in intra- and interspecific crosses. Ahuja et al. (2004) in a selection experiment found high estimates of genetic coefficient of variation and heritability for seed cotton yield /plant, number of bolls / plant and boll weight. Basbag and Gencer (2004) stated that the characters of high heritability estimates; boll weight, seed index, fiber fineness and fiber strength could be selected in the early generations (F2 and F3), while that of low heritability as number of bolls/ plant selection should be postponed to latter generations. The phenotypic and genotypic coefficients of variation were larger in the F2 than those of the succeeding generations (Gooda 2007, Srour et al. 2010 and Abou El-Yazied et al. 2013). Large discrepancies between actual and predicted gains were obtained (ElHarony, 1998, Okasha, 1998, Youns, 1999 and El-Defrawy and El-Ameen, 2004 and Abd El-Zaheret al. 2007). Otherwise, Gooda (2007) found that actual genetic gain for most selected traits was higher than predicted gain except lint percentage. Khan et al. (2009) and Soomro et al. (2010) in
Upland cotton and Mahdy et al. (2006), Mahdy et al. (2009 a and b) and Srour et al. (2010) in Egyptian cotton recorded high genetic gain for bolls/plant, boll weight and for seed cotton yield. The main objective of this work was to evaluate the method of maintaining and renewing the breeder seeds of Giza 90 followed by Maintenance Research Section for renewing the Egyptian cotton strains and varieties, Cotton Research Institute, ARC, and the possibility of selection elite high yielding plants characterized by the same fiber properties of Giza 90. To attain this goal single trait selection for lint yield, lint percentage and earliness was applied for two cycles on the same materials used for producing Giza 90 nucleolus.

\section{Materials and Methods}

The present study was carried out at Shandaweel Res. Sta. Sohag, Cotton Res. Inst., A.R.C. during the three summer seasons of $2013-2015$. The basic materials were selfed seeds of 60 single plants selected from the breeding nursery of renewal and maintenance of Giza 90 (the same materials used for producing the nucleolus of G.90). Giza 90 is traced back to a cross between Giza $83 \mathrm{x}$ Dandara, and released commercially in year 2000. G.90 is a commercial Egyptian cotton cultivar ( $G$. barabadenseL.) cultivated at upper and middle Egypt regions and characterized by high yielding ability, high ginning outturn (more than 120 pounds), and early maturity with staple length of about $31 \mathrm{~mm}$. These materials were subjected to pedigree single trait selection for lint yield/plant, lint yield/plant restricted 
by days to first flower and lint percentage. The traditional method followed by Cotton Maintenance Res. Sec. for renewing and maintenance of Egyptian cotton was represented by check strain (the newest nucleolus of Giza 90) in the experiment each year.

In season 2013; selfed seeds of the 60 selected plants were planted on

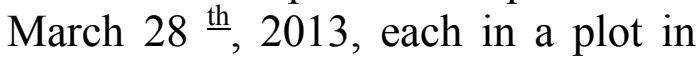
the breeding nursery. Each plot included five rows (10 plants in rows) $7.0 \mathrm{~m}$ long, $60 \mathrm{~cm} \mathrm{~m}$ apart and $70 \mathrm{~cm}$ between hills within a row. The middle row was left without planting to facilitate plant screening and selfing. The total number of selfed plants were 847. At flowering, days to first flower (DFF) was recorded for each plant. After picking at the end of the season the following characters were recorded for each single plant; seed cotton yield /plant; g (SCY/P; g), lint yield /plant; g (LY/P; g), lint percentage (lint \%) [lint yield/seed cotton yield], number of bolls/plant (NB/P), number of seeds/boll (NS/B) [boll weight $\mathrm{x}$ (100-lint\%) /seed index], Micronaire reading (Mic), fiber strength as Pressley index measured by the H.V.I instrument (PI) and Upper half mean length; mm as measured by the H.V.I. instrument (UHM). Selfedseeds of the best 20 single plants in LY/P, LY/P restricted by DFF (the best LY/P less than the population mean in DFF), Lint $\%$ andDFF were saved for season 2014.

In season 2014; The selected plants of the 4 selection procedures were planted on April 1 1t, 2014 season. The selfed seeds of each selected plant were used in planting. A randomized complete blocks design of three replications was used. The plot was single row $4 \mathrm{~m}$ in length, $60 \mathrm{~cm}$ apart and $50 \mathrm{~cm}$ between hills within a row. One row was left without planting between each two rows to facilitate selfing and screening. After full emergence seedlings were thinned to one plant/hill. The recommended cultural practices for cotton production were adopted thought the growing season. The studied characters were recorded as in the previous season. The selfed seeds of the best 10 plants for each procedure were saved for evaluation in the next season.

In Season 2015; Selfed seeds of the selected plants from season 2014 along with G.90 nucleolus (the nucleolus produced from the same basic materials) were planted on March 25 th, 2015 in a randomized complete blocks design of three replications as in the previous season. The studied characters were recorded as in the previous season.

\section{Statistical analysis}

Estimates of genotypic and phenotypic variances were calculated from expected mean squares components of the selected families as outlined by Al-jibouri et al. (1958). The analysis of variance was done two times for each trait, the first was for the selected families only to estimate phenotypic and genotypic coefficients of variability and heritability in broad sense. The second was for the selected families along with the check strain to make mean separation between selected families and the check strain. Heritability in broad sense was estimated as: $(H)=(\sigma 2 g / \sigma 2 p) x$ 100. The phenotypic (PCV\%) and genotypic $(\mathrm{GCV} \%)$ coefficients of variation were estimated as Burton 
(1952). Mean comparisons were calculated using revised L.S.D according to (El Rawi and Khalafalla (1980).

$\mathrm{R} \mathrm{L} \mathrm{S} \mathrm{D} \alpha=\left(\mathrm{t}^{-}\right) \alpha * \sqrt{ }(2 \mathrm{MSE} / \mathrm{r})$ Where $\mathrm{t}^{-}$is the $\mathrm{t}$ value from "minimum-average-risk t-table" at F-value of genotypes, genotypes df and experimental error df. The significance of observed direct and correlated response to selection was measured as the deviation percentage of a family mean from the newest nucleolus (check strain) using R. L. S. D.

\section{Results and Discussion}

1-Description of the base population; season 2013

Means and coefficient of variation

Seed cotton yield /plant, lint yield/plant and number of bolls /plant showed wide range of variation accompanied with high coefficients of variation of $39.70,39.52$ and $39.45 \%$ for $\mathrm{SCY} / \mathrm{P}, \mathrm{Ly} / \mathrm{p}$ and $\mathrm{NB} / \mathrm{p}$; respectively (Table 1 ). The coefficient of variability was medium for boll weight and number of seeds/boll and accounted for 8.40 and $8.75 \%$; respectively. Otherwise, the coefficients of variability in seed index, lint index, days to first flower and technological properties were low and ranged from 2.49 for days to first flower to $7.40 \%$ for Micronaire reading. These results reflect the method of renewing strains and varieties of Egyptian cotton. The breeder devotes his effort to insure technological properties; fineness, strength and fiber length, and selects the plants matched Giza 90 type in fiber properties irrespective of their yield and its components. Therefore, the coefficients of variability of Micronaire reading, Pressely index and upper half- mean length were low, reflecting the great similarity of the plants in fiber properties. Likewise, the coefficients variability in seed index, lint index and days to first flower were low as in all the Egyptian cottons. The high coefficients of variability of seed cotton yield / plant, lint yield/plant, number of bolls/plant and boll weight indicated to the feasibility of selection for these traits with good preservation of fiber properties. The results of PCV in the base population are in general agreement with those reported by Mahdy et al. 2006;2007; 2009a,b; and 2013a,b; and Hassaballa et al. (2012) respect to cotton yield and NB/P. But, low respect to SI, LI and Maturity. 
Table 1. Average, maximum, minimum and coefficient of variation of the studied traits of the base population and the adopted selection procedures; season 2013.

\begin{tabular}{|c|c|c|c|c|c|c|c|c|c|c|c|c|}
\hline \multicolumn{10}{|c|}{ Base Population } \\
\hline & SCY/P;g & LY/P;g & Lint\% & NB/P & BW;g & SI;g & LI;g & NS/b & DFF & MIC & PI & UHM \\
\hline Average \pm & 150.77 & 58.69 & 39.00 & 47.82 & 3.15 & 9.86 & 6.30 & 30.00 & 68.81 & 3.82 & 9.71 & 30.17 \\
SE & \pm 2.06 & \pm 0.80 & \pm 0.025 & \pm 0.65 & \pm 0.01 & \pm 0.02 & \pm 0.01 & \pm 0.09 & \pm 0.06 & \pm 0.01 & \pm 0.02 & \pm 0.06 \\
\hline Max. & 430.00 & 167.60 & 42.10 & 138.00 & 3.90 & 12.00 & 7.87 & 37.00 & 75.00 & 4.90 & 11.60 & 39.70 \\
\hline Min. & 24.60 & 9.40 & 37.20 & 9.11 & 2.70 & 8.30 & 5.37 & 19.00 & 64.00 & 2.80 & 8.40 & 21.00 \\
\hline C.V\% & 39.70 & 39.52 & 1.85 & 39.45 & 8.40 & 5.37 & 5.26 & 8.57 & 2.49 & 7.40 & 4.83 & 5.70 \\
\hline
\end{tabular}

$\mathrm{SE}=$ standard error, c.v. $=$ coefficient of variability, $\mathrm{Max}=$ maximum and $\mathrm{Min}=$ minimum

\section{2-Second cycle selection}

2-1. Mean squares and coefficient of variability

Genotypes mean squares (Table2) of traits of the selected families (without the check) for LY/P was not significant for $\mathrm{LY} / \mathrm{P}$ and $\mathrm{SCY} / \mathrm{P}$ (not included) indicating the depletion of genetic variance among families and insufficient genetic variability for further cycles of selection. The other traits showed significant ( $p \leq 0.05$ to $\mathrm{p} \leq 0.01$ ) genotypes mean squares, however, the coefficients of variability were very low. The genotypic coefficient of variability ranged from 1.01 for seed index to $4.84 \%$ for BW. These results indicated that two cycles of pedigree selection for LY/P were enough to isolate the best high yielding families. This mainly due to that the materials under study were subjected to selfing for many years, which resulted in a narrow group of homozygous lines similar in pheno- typic performance. Otherwise, genotypes mean squares of families selected for $\mathrm{LY} / \mathrm{P}$ restricted by $\mathrm{DFF}$ was significant $(\mathrm{p} \leq 0.01)$ for all traits except for Pressley index. This indicates that selection for more than one character preserves genetic variability. The genetic coefficients of variability were medium for LY/P $(8.99 \%)$ with high estimate of broad sense heritability $(79.46 \%)$, and very low for DFF $(2.47 \%)$ with high estimate of heritability $(95.78 \%)$. The coefficient of genetic variability of the other traits was low and ranged from $1.31 \%$ for $\operatorname{lint} \%$ to $6.22 \%$ for NB/P.

Genotypes mean squares of traits of the selected families for lint $\%$ was not significant for $\mathrm{SCY} / \mathrm{P}$, LY/P, Lint $\%$ and Pressley index indicating complete depletion of genetic variability for the selection criterion. Genetic coefficient of variation of the other traits ranged from 1.23 for DFF to $8.30 \%$ for $\mathrm{NB} / \mathrm{P}$. 
Table 2. Mean squares, genotypic (GCV\%), phenotypic (PCV\%) coefficients of variability and broad sense heritability $(\mathrm{H} \%)$ of different selection criteria and correlated traits after two cycle of pedigree selection; season 2015. (ANOVA with check)

\begin{tabular}{|c|c|c|c|c|c|c|c|c|c|c|c|c|c|}
\hline \multirow{2}{*}{ S.V. } & \multirow{2}{*}{$\mathbf{d} \mathbf{f}$} & \multicolumn{12}{|c|}{ Mean squares } \\
\hline & & SCY/P & $\mathrm{LY} / \mathrm{P}$ & LINT\% & $\mathrm{NB} / \mathrm{P}$ & BW & Seed I & Lint I & NS/B & DFF & MIC & PI & UHM \\
\hline \multicolumn{14}{|c|}{ 1- Pedigree selection for LY/P } \\
\hline Reps & 2 & 4.66 & 1.49 & 0.14 & 0.88 & 0.01 & 0.08 & 0.08 & 1.85 & 0.36 & 0.02 & 0.22 & 0.35 \\
\hline Genotypes & 10 & $142.76^{* *}$ & $25.36 * *$ & $0.79 * *$ & $9.73 *$ & $0.08^{* *}$ & $0.14 *$ & $0.14^{*}$ & $1.88 * *$ & $2.27 * *$ & $0.06^{*}$ & $0.37 * *$ & $4.23 * *$ \\
\hline $\begin{array}{l}\text { Exper. } \\
\text { Error }\end{array}$ & 20 & 41.67 & 7.21 & 0.17 & 4.11 & 0.02 & 0.05 & 0.04 & 0.35 & 0.36 & 0.02 & 0.08 & 0.41 \\
\hline GCV\% & & - & - & 1.23 & - & 4.84 & 1.01 & 2.91 & 3.96 & 1.24 & 3.11 & 3.34 & 3.89 \\
\hline $\mathrm{PCV} \%$ & & - & - & 1.39 & - & 5.51 & 1.74 & 3.54 & 4.36 & 1.35 & 3.78 & 3.79 & 4.09 \\
\hline $\mathrm{H} \%$ & & & & & & & & & & & & & \\
\hline \multicolumn{14}{|c|}{ 2- Pedigree selection for LY/P restricted by DFF } \\
\hline Reps & 2 & 104.88 & 15.86 & 0.03 & \begin{tabular}{|l|}
2.23 \\
\end{tabular} & \begin{tabular}{|l|}
0.02 \\
\end{tabular} & 0.006 & 0.01 & 1.18 & 0.12 & 0.05 & 0.43 & 0.003 \\
\hline Genotypes & 10 & $285.56^{* *}$ & $47.23 * *$ & $0.91 * *$ & $17.69^{*}$ & $0.09 * *$ & $0.27 * *$ & $0.29 * *$ & $2.28 * *$ & $8.08^{* * *}$ & $0.11 * *$ & 0.10 & $1.38 * *$ \\
\hline $\begin{array}{l}\text { Exper. } \\
\text { Error }\end{array}$ & 20 & 58.44 & 8.92 & 0.10 & 6.37 & 0.01 & 0.03 & 0.01 & 0.55 & 0.32 & 0.02 & 0.09 & 0.34 \\
\hline GCV\% & & 8.58 & 8.99 & 1.31 & 6.22 & 5.15 & 3.08 & 4.89 & 3.98 & 2.47 & 4.46 & - & 1.65 \\
\hline PCV\% & & 9.71 & 10.09 & 1.45 & 7.83 & 5.77 & 3.24 & 4.97 & 4.59 & 2.52 & 5.17 & - & 2.00 \\
\hline $\mathrm{H} \%$ & & & 79.46 & & & & & & & 95.78 & & & \\
\hline \multicolumn{14}{|c|}{ 3- Pedigree selection for Lint $\%$} \\
\hline Reps & 2 & 61.29 & 12.63 & 0.16 & 7.35 & 0.09 & 0.05 & 0.07 & 0.85 & 0.36 & 0.03 & 0.23 & 0.36 \\
\hline Genotypes & 10 & 155.37 & $28.45^{*}$ & $0.99 * *$ & $28.26^{*}$ & 0.12 & $0.38^{* *}$ & $0.14 * *$ & $5.27 * *$ & $2.45 * *$ & $0.17 * *$ & 0.33 & $1.45^{* *}$ \\
\hline $\begin{array}{l}\text { Exper. } \\
\text { Error }\end{array}$ & 20 & 77.56 & 12.13 & 0.23 & 10.16 & 0.07 & 0.04 & 0.02 & 0.28 & 0.36 & 0.03 & 0.13 & 0.27 \\
\hline GCV\% & & 5.33 & 4.96 & 0.38 & 8.30 & 6.76 & 3.30 & 2.25 & 6.90 & 1.23 & 5.81 & 1.01 & 1.84 \\
\hline PCV\% & & 7.55 & 7.25 & 0.83 & 10.18 & 7.02 & 3.49 & 2.57 & 7.12 & 1.34 & 6.55 & 2.38 & 2.10 \\
\hline $\mathrm{H} \%$ & & & & 21.16 & & & & & & & & & \\
\hline \multicolumn{14}{|c|}{ 4- Pedigree selection for DFF } \\
\hline Reps & 2 & 24.97 & 3.71 & 0.006 & 9.63 & 0.03 & 0.08 & 0.04 & 0.64 & 0.48 & 0.05 & 0.46 & 0.04 \\
\hline Genotypes & 10 & $160.13 * *$ & $24.90 * *$ & $0.70 * *$ & $24.34 *$ & $0.06^{*}$ & $0.40 * *$ & $0.13^{*}$ & 0.70 & $3.95 * *$ & $0.09 *$ & $0.84 * *$ & $1.19 * *$ \\
\hline $\begin{array}{l}\text { Exper. } \\
\text { Error }\end{array}$ & 20 & 45.66 & 5.81 & 0.16 & 7.71 & 0.02 & 0.06 & 0.05 & 1.07 & 0.35 & 0.03 & 0.16 & 0.30 \\
\hline GCV\% & & 4.44 & 4.81 & 1.16 & 6.73 & - & 3.52 & 2.76 & - & 0.88 & 3.51 & 4.68 & 1.60 \\
\hline $\mathrm{PCV} \%$ & & 5.89 & 5.99 & 1.31 & 8.35 & - & 3.84 & 3.42 & - & 1.04 & 4.60 & 5.28 & 1.93 \\
\hline $\mathrm{H} \%$ & & & & & & & & 64.96 & & & & & \\
\hline
\end{tabular}

zero or negative genotypic variance.*and**; significant at 0.05 and 0.01 levels of probability; respectively

Mean squares of genotypes for different traits was significant $(\mathrm{P} \leq$ 0.05 to $\mathrm{P} \leq 0.01)$ when selection practiced DFF. The genotypic coefficient of variability was very low for DFF with $64.96 \%$ heritability estimate. Generally, selection for DFF dropped rapidly the $\mathrm{GCV} \%$ for all traits after two cycles of selection.

Generally, it could be concluded that two cycles of selection for the different selection procedures were enough to isolate favorable families.
Two cycles of selection dropped rapidly the genotypic and phenotypic coefficients of variability. The PCV\% of $\mathrm{LY} / \mathrm{P}$ decreased from $39.52 \%$ in the base population to an estimate of zero after two cycles of selection for $\mathrm{LY} / \mathrm{P}$, decreased from $1.85 \%$ to zero for $\operatorname{lint} \%$, and from 2.49 to $1.04 \%$ for DFF, when selection practiced for these traits. This could be due to that the system followed by Maintenance Research Section for cotton varieties devotes great attention to the varietal 
type of Giza 90 respect to the fiber properties rather than yield. In consequence, selfing for many years in the breeding nursery of Giza 90 resulted in a narrow group of homozygous lines similar to large extent in fiber properties and plant phenology, but not in yield. Therefore, two cycles of selection for yield succeeded to isolate high yielding families look like Giza 90 in fiber properties which could be called pure line selection. Ahuja et al. (2004) found high estimates of GCV and heritability for $\mathrm{SCY} / \mathrm{P}, \mathrm{NB} / \mathrm{P}$ and BW. Naveed et al. (2004) noted heritability estimates of $22,23,33,35$ and $38 \%$ for $\mathrm{BW}$, Lint $\%$, SCY/P, plant height and $\mathrm{NB} / \mathrm{P}$; respectively. Ahmed et al. (2006) showed medium to high heritability estimates for lint percentage, SCY/P, NB, boll weight and fiber length. Tang et al. (2009) reported high estimates of GCV and heritability for SCY/P, LY/P and NB/P. Srour et al. (2010) reported decrease in $\mathrm{PCV} \%$ and GCV\% from F2 to F3 for all traits. Many researchers (Mahdy et al. 2006; Mahdy et al. 2007; Mahdy et al. 2009a,b ; Hassaballa et al. 2012 and Mahdy et al. 2013a,b) showed high estimates of $\mathrm{PCV}$ and GCV\% in the base populations which decreased after two cycles of selection for different selection criteria.

\section{2-2. Pedigree selection for lint yield / plant}

Two cycles of pedigree selection for LY/P results in a mean of the selected families significant $(\mathrm{P} \leq 0.05$ to $\mathrm{P} \leq 0.01$ ) out yielded the check strain for SCY/P, LY/P and NB/P (Table3). The means of the other traits did not differ from the check strain. Nine out of ten individual families showed significant increase in yields than the check strain. The observed genetic gain (Table 4) indicated that nine, 1, 7, 2, 1, 1, 2 and 4 families significant $(\mathrm{P} \leq 0.05$ to $\mathrm{P} \leq$ 0.01 ) exceeded the check strain in yields, lint $\%$, NB/P, BW, SI, LI, NS/B, PI and UHM length; respectively. The significant genetic observed gain in the selection criterion $\mathrm{LY} / \mathrm{P}$ ranged from 14.59 to $27.19 \%$ of the check strain. Cotton breeder always seeks for the superior plants in the late generation. Two cycles of pedigree selection resulted in a superior family No.334. This family significant exceeded the newest check strain by $22.92,2719,3.46,15.14$, $8.59,-10.26$ and $4.08 \%$ for SCY/P, LY/P, Lint \%, NB/P, LI, Micronaire reading and UHM length; respectively. The other traits of family No.334 did not differ from the check strain. These results ascertain that in the official system of renewing the strains and varieties of Egyptian cotton, the breeder devotes all his effort to preserve the type of Giza 90 variety in fiber properties ignoring yield. Gomaa et al. (1999) found high response to selection for SCY/P. Mahrous (2004) stated that the observed gain in SCY/P was correlated with significant response in $\mathrm{LY} / \mathrm{P}$, NB/P, BW and Lint\%. Mahdy et al. (2009b) showed genetic observed gain ranged from $8.89-25.21 \%$ of the better parent for SCY/P after two cycles of selection. Mahdy et al. (2013a) achieved average observed gain in LY/P after two cycles of selection of 21.15 and $18.20 \%$ of the better parent in two populations. 
2-3. Pedigree selection for lint yield/plant restricted by days to first flower

The overall means of the selected families indicated significant improvement in LY/P, Lint $\%, B W$, LI, DFF and UHM length (Table 5). Theobserved genetic gain (Table 6) showed significant increase of the overall mean than the check of $11.54 \%$ for $\mathrm{LY} / \mathrm{P}, 1.13 \%$ for $\mathrm{Lint} \%$, $4.63 \%$ for BW, $2.35 \%$ for LI, $1.81 \%$ for DFF and $3.58 \%$ for UHM length. The observed gain of the individual families showed that three families were significant $(P \leq 0.01)$ earlier than the check by -1.96 to $5.39 \%$.

Table 3. Means of the studied traits after two cycles of selection for LY/P; season 2015

\begin{tabular}{|c|c|c|c|c|c|c|c|c|c|c|c|c|}
\hline Ser & SCY/P;g & LY/P;g & lint\% & $\mathrm{NB} / \mathrm{P}$ & BW & SI;g & LI;g & NS/B & DFF & MIC & PI & UHM \\
\hline 334 & 112.90 & 45.10 & 39.94 & 35.69 & 3.17 & 9.57 & 6.95 & 19.67 & 67.33 & 3.50 & 9.80 & 31.43 \\
\hline 19 & 113.13 & 44.33 & 39.18 & 32.63 & 3.47 & 10.27 & 6.28 & 20.33 & 68.67 & 3.73 & 10.27 & 27.83 \\
\hline 31 & 116.07 & 44.77 & 38.56 & 34.73 & 3.35 & 10.17 & 6.18 & 20.33 & 67.33 & 3.83 & 9.80 & 32.10 \\
\hline 27 & 100.77 & 38.37 & 38.09 & 34.38 & 2.93 & 10.00 & 6.15 & 18.00 & 68.33 & 3.73 & 9.77 & 30.00 \\
\hline 690 & 110.97 & 43.07 & 38.82 & 36.18 & 3.07 & 10.00 & 6.47 & 19.00 & 67.67 & 3.73 & 9.57 & 30.17 \\
\hline 361 & 112.37 & 43.57 & 38.75 & 36.43 & 3.09 & 9.80 & 6.43 & 19.33 & 67.33 & 3.93 & 9.70 & 31.63 \\
\hline 767 & 105.60 & 40.63 & 38.46 & 35.99 & 2.93 & 9.93 & 6.29 & 18.00 & 68.33 & 3.73 & 9.77 & 30.00 \\
\hline 265 & 111.30 & 42.53 & 38.21 & 36.84 & 3.02 & 9.67 & 6.40 & 19.33 & 70.33 & 3.87 & 8.80 & 31.60 \\
\hline 32 & 109.77 & 42.33 & 38.58 & 36.27 & 3.03 & 10.03 & 6.27 & 18.67 & 68.00 & 3.77 & 9.50 & 29.97 \\
\hline 3 & 107.03 & 41.90 & 39.13 & 34.30 & 3.12 & 10.13 & 6.35 & 18.67 & 67.67 & 4.03 & 9.67 & 30.20 \\
\hline Mean & 109.99 & 42.66 & 38.77 & 35.34 & 3.12 & 9.96 & 6.38 & 19.13 & 68.10 & 3.79 & 9.66 & 30.49 \\
\hline check & 91.85 & 35.46 & 38.60 & 31.00 & 3.00 & 9.80 & 6.40 & 19.00 & 68.00 & 3.90 & 9.50 & 30.20 \\
\hline $\begin{array}{l}\text { RLSD } \\
0.05 \text { for } \\
\text { mean } 1\end{array}$ & 8.95 & 3.72 & 0.54 & 3.14 & 0.18 & 0.33 & 0.28 & 0.77 & 0.73 & 0.21 & 0.37 & 0.7 \\
\hline $\begin{array}{l}\text { RLSD } \\
0.01 \text { for } \\
\text { mean }\end{array}$ & 12.66 & 5.27 & 0.74 & 4.62 & 0.25 & 0.48 & 0.39 & 0.98 & 1.00 & 0.30 & 0.51 & 1.04 \\
\hline $\begin{array}{l}\text { RLSD } \\
0.05 \text { for } \\
\text { families } 2\end{array}$ & 12.07 & 5.02 & 0.72 & 4.24 & 0.25 & 0.44 & 0.37 & 1.04 & 0.99 & 0.28 & 0.50 & 1.05 \\
\hline $\begin{array}{l}\text { RLSD } \\
0.01 \text { for } \\
\text { families }\end{array}$ & 17.08 & 7.10 & 1.00 & 6.22 & 0.34 & 0.64 & 0.53 & 1.32 & 1.34 & 0.41 & 0.68 & 1.40 \\
\hline \multicolumn{13}{|c|}{ 1- to compare mean with the check } \\
\hline & & & & & & & & & & & & \\
\hline
\end{tabular}

Significant observed gain was found for five families in lint $\%$, BW and lint index, two families in Micronaire reading and seven families in UHM length. The best superior promising families were family No.31. Family No.334 was the superior family selected in the previous selection procedure; LY/P. Family No. 31 ex- ceeded the check by $26.25 \%$ in $\mathrm{LY} / \mathrm{P}$, $11.56 \%$ in BW, $3.47 \%$ in Seed index, $7.02 \%$ in $\mathrm{Ns} / \mathrm{B}$ and $6.29 \%$ in UHM Length.

2-4. Pedigree selection for lint percentage

The overall mean of the selected families for $\operatorname{lint} \%$ significant $(\mathrm{P} \leq$ 0.01 ) exceeded the check strain in the 
selection criterion (Table 7). Significant increases of the overall mean were observed for SI, LI and UHM length. The other correlated traits; SCY/P, LY/P, NB/P, BW, NS/B, Micronaire reading and Pressley index did not show significant increase than the check. The genetic observed gain (Table 8) indicated that pedigree selection is an efficient method to im- prove the selection criterion; lint $\%$. Nine out of the ten selected families showed significant genetic observed gain in lint \% ranged from 2.77 to $5.42 \%$ of the check strain. The observed genetic gain showed $3,3,5,4$, 1,2 and 4 families exceeded the check strain for LY/P, BW, SI, LI, NS/B, PI and UHM length.

Table 4. Observed genetic gain from selection for $L Y / P$ after the second cycle in percentage from the check strain; season 2015

\begin{tabular}{|c|c|c|c|c|c|c|c|c|c|c|c|c|}
\hline Ser & SCY/P;g & LY/P;g & lint $\%$ & $\mathbf{N B} / \mathbf{P}$ & BW & SI;g & LI;g & NS/B & \begin{tabular}{|l|l|} 
DFF \\
\end{tabular} & MIC & PI & UHM \\
\hline 334 & $22.92 * *$ & $27.19 * *$ & $3.46^{* *}$ & 15.14* & 5.56 & -2.38 & $8.59 * *$ & 3.51 & \begin{tabular}{|l|}
-0.98 \\
\end{tabular} & $-10.26^{*}$ & 3.16 & $4.08^{*}$ \\
\hline 19 & $23.17 * *$ & $25.02 * *$ & 1.51 & 5.26 & $15.56^{* *}$ & $4.76^{*}$ & -1.93 & $7.02 * *$ & 0.98 & -4.27 & $8.07 * *$ & $-7.84 * *$ \\
\hline 31 & $26.37 * *$ & $26.25 * *$ & -0.09 & 12.03 & $11.56^{* *}$ & 3.74 & -3.49 & $7.02 * *$ & -0.98 & -1.71 & 3.16 & $6.29 * *$ \\
\hline 27 & 9.71 & 8.20 & -1.33 & 10.90 & -2.22 & 2.04 & -3.85 & -5.26 & 0.49 & -4.27 & 2.81 & -0.66 \\
\hline 690 & $20.81 * *$ & $21.45 * *$ & 0.57 & $16.72 *$ & 2.22 & 2.04 & 1.04 & 0.00 & -0.49 & -4.27 & 0.70 & -0.11 \\
\hline 361 & $22.34 * *$ & $22.86^{* *}$ & 0.38 & $17.51 *$ & 3.11 & 0.00 & 0.42 & 1.75 & -0.98 & 0.85 & 2.11 & $4.75^{* *}$ \\
\hline 767 & $14.97 *$ & $14.59 *$ & -0.35 & $16.09 *$ & -2.22 & 1.36 & -1.67 & -5.26 & 0.49 & -4.27 & 2.81 & -0.66 \\
\hline 265 & $21.18 * *$ & $19.95 *$ & -1.02 & $18.82 *$ & 0.67 & -1.36 & 0.05 & 1.75 & 3.43 & -0.85 & -7.37 & $4.64 * *$ \\
\hline 32 & $19.51 * *$ & $19.38^{*}$ & -0.06 & 17.01* & 0.89 & 2.38 & -2.08 & -1.75 & 0.00 & -3.42 & 0.00 & -0.77 \\
\hline 3 & $16.53 *$ & $18.16^{*}$ & 1.38 & 10.63 & 4.11 & 3.40 & -0.83 & -1.75 & -0.49 & 3.42 & 1.75 & 0.00 \\
\hline Mean & $19.75^{* *}$ & $20.30 * *$ & 0.44 & $14.01 *$ & 3.92 & 1.60 & -0.38 & 0.70 & 0.15 & -2.91 & 1.72 & 0.97 \\
\hline & & & & & & & & & & & & \\
\hline $\begin{array}{l}\text { RLSD } \\
0.05 \% \text { for } \\
\text { mean } 1\end{array}$ & 9.745 & 10.500 & 1.391 & 10.138 & 6.137 & 3.357 & 4.333 & 4.054 & 1.079 & 5.336 & 3.876 & 2.567 \\
\hline $\begin{array}{l}\text { RLSD } \\
0.01 \% \text { for } \\
\text { mean }\end{array}$ & 13.788 & 14.856 & 1.915 & 14.890 & 8.449 & 4.850 & 6.131 & 5.166 & 1.464 & 7.707 & 5.336 & 3.445 \\
\hline $\begin{array}{l}\text { RLSD } \\
0.05 \% \text { for } \\
\text { families } 2\end{array}$ & 13.141 & 14.159 & 1.875 & 13.670 & 8.275 & 4.527 & 5.843 & 5.466 & 1.455 & 7.195 & 5.227 & 3.461 \\
\hline $\begin{array}{l}\text { RLSD } \\
0.01 \% \text { for } \\
\text { families } \\
\end{array}$ & 18.592 & 20.032 & 2.582 & 20.077 & 11.393 & 6.539 & 8.267 & 6.966 & 1.974 & 10.392 & 7.196 & 4.645 \\
\hline & & & & & & & & & & & & \\
\hline
\end{tabular}

- *and **; significant at 0.05 and $0.01 \%$ levels of probability; respectively.

\section{2-5. Pedigree selection for days to first flower (DFF)}

Mean days to first flower (Table 9) of the selected families for two cycles of selection ranged from 64.33 to 65.67 with an earlier $(\mathrm{P} \leq 0.05)$ average of 64.83 compared to 68.0 days for the check strain.

The observed genetic gain (Table 10) of the selection criterion; DFF was earlier $(p \leq 0.01)$ than the check strain for all the selected families and ranged from -2.45 to $-5.39 \%$ of the check. Six families showed significant observed genetic gain in SCY/P ranged from 14.43 to 26.15 with an average of $15.43 \%$ of the check. Seven families showed significant genetic gain in LY/P ranged from 14.59 to $29.44 \%$ of the check. Respect to the other correlated gains; 1, 4, 2, 3, 1, 3 and 5 families showed significant genetic gain from the check strain for lint $\%, \mathrm{NB} / \mathrm{P}, \mathrm{BW}, \mathrm{SI}$, LI, PI, and UHM length; respectively. 
Table 5. Means of the studied traits after two cycles of selection for LY/P restricted by DFF; season 2015

\begin{tabular}{|c|c|c|c|c|c|c|c|c|c|c|c|c|}
\hline Ser & SCY/P;g & LY/P;g & lint $\%$ & NB/P & BW & SI;g & LI;g & NS/B & DFF & MIC & PI & UHM \\
\hline 334 & 112.900 & 45.100 & 39.936 & 35.692 & 3.167 & 9.567 & 6.950 & 19.667 & 67.333 & 3.500 & 9.800 & 31.433 \\
\hline 54 & 98.833 & 38.700 & 39.155 & 32.956 & 3.000 & 9.267 & 6.943 & 19.667 & 64.667 & 3.533 & 9.633 & 31.567 \\
\hline 31 & 116.067 & 44.767 & 38.564 & 34.728 & 3.347 & 10.167 & 6.177 & 20.333 & 67.333 & \begin{tabular}{|l|}
3.833 \\
\end{tabular} & 9.800 & 32.100 \\
\hline 700 & 96.400 & 37.300 & 38.694 & 31.770 & 3.033 & 9.867 & 6.400 & 19.000 & 68.333 & 3.733 & 9.900 & 31.533 \\
\hline 699 & 103.900 & 40.400 & 38.883 & 34.680 & 3.000 & 9.633 & 6.603 & 19.000 & 66.667 & 4.067 & 9.833 & 31.267 \\
\hline 3 & 107.033 & 41.900 & 39.132 & 34.296 & \begin{tabular}{|l|}
3.123 \\
\end{tabular} & 10.133 & 6.347 & 18.667 & 67.667 & \begin{tabular}{|l|l|}
4.033 \\
\end{tabular} & 9.667 & 30.200 \\
\hline 105 & 101.367 & 40.533 & 39.998 & 29.515 & 3.433 & 9.667 & 6.897 & 21.333 & 64.333 & 3.733 & 9.600 & 31.100 \\
\hline 354 & 80.900 & 31.667 & 39.143 & 28.546 & 2.833 & 9.467 & 6.797 & 18.333 & 64.667 & 3.933 & 9.767 & 30.233 \\
\hline 362 & 95.833 & 36.767 & 38.352 & 30.165 & 3.173 & 10.067 & 6.183 & 19.667 & 67.333 & 3.800 & 9.500 & 31.500 \\
\hline 48 & 99.800 & 38.400 & 38.510 & 30.484 & 3.280 & 10.100 & \begin{tabular}{|l|}
6.207 \\
\end{tabular} & 20.333 & 69.333 & \begin{tabular}{|l|}
4.000 \\
\end{tabular} & 10.133 & 31.867 \\
\hline mean & 101.303 & 39.553 & 39.037 & 32.283 & 3.139 & 9.793 & 6.550 & 19.600 & 66.767 & 3.817 & 9.763 & 31.280 \\
\hline Check & 91.850 & 35.460 & 38.600 & 31.000 & 3.000 & 9.800 & 6.400 & 19.000 & 68.000 & 3.900 & 9.500 & 30.200 \\
\hline $\begin{array}{l}\text { RLSD } 0.05 \% \text { for } \\
\text { mean } 1\end{array}$ & 9.952 & 3.888 & 0.387 & 3.714 & 0.122 & 0.202 & 0.117 & 0.966 & 0.634 & 0.184 & - & 0.759 \\
\hline $\begin{array}{l}\text { RLSD } 0.01 \% \text { for } \\
\text { mean }\end{array}$ & 13.702 & 4.955 & 0.525 & 5.364 & 0.166 & 0.272 & 0.157 & 1.329 & 0.846 & 0.253 & - & 1.045 \\
\hline $\begin{array}{l}\text { RLSD } 0.05 \% \text { for } \\
\text { families } 2\end{array}$ & 13.420 & 5.243 & 0.522 & 5.008 & 0.165 & 0.273 & 0.158 & 1.302 & 0.854 & 0.248 & - & 1.024 \\
\hline $\begin{array}{l}\text { RLSD } 0.01 \% \text { for } \\
\text { families }\end{array}$ & 18.476 & 6.682 & 0.707 & 7.233 & 0.224 & 0.366 & 0.211 & 1.792 & 1.141 & 0.342 & - & 1.409 \\
\hline & & & & & & & & & & & & \\
\hline
\end{tabular}

The best promising families were family No.73, No. 75, No. 156 and No. 335. Families No. 73 and No. 75 were earlier and out yielded $(\mathrm{P} \leq$ $0.01)$ the check strain. Family No. 156 was earlier, out yielded the check and better in Pressley index. Family No. 335 was earlier, high yielding and better than the check strain in both of Pressley index and UHM length. Mahdy et al. (2006) increased earliness index after two cycles of selection from 3.85 to $15.38 \%$, and from 16.67 to $23.61 \%$ of the better parent in two populations. Hassaballa et al. (2012) increased earliness index in a population by $14.17 \%$ of the better parent after two cycles of selection.

\section{3- General comparison between the adopted selection procedures}

It should be recalled that one of the goals of this work was to identify high yielding families matched the type of Giza 90 cultivar in fiber prop- erties. Average of the ten selected families (Table11) indicated that selection for $\mathrm{LY} / \mathrm{P}$ ranked the first and improved LY/P by $20.30 \%$ of the check strain followed by DFF method (15.82\%), and LY/P restricted by DFF (11.54\%). Generally, single trait selection is an effective method to improve selection criterion. Respect to the observed genetic gain in LY/P of the individual families, the best families were family No. 73 (29.44\% - DFF), family No. 334 (27.91\% LY/P). Family NO.334 showed significant observed genetic gain in SCY/P, LY/p, lint \%, NB/p, Si, UHM length and Micronaire reading. Among these superior families, family No. 590 (lint\% procedure), family No.165 and family No.335(DFF procedure) characterized by strongest fiber beside cotton yields. It could be concluded that the adopted selection procedures identified superior high yielding families and better than the 
newest check strain derived from the same materials in one or more of the main fiber properties. Therefore, the official method of maintaining and renewing Egyptian cotton varieties should be modified to allow selection for yield beside preserving fiber properties.

Table 6. Observed genetic gain from selection for $L Y / P$ restricted by DFF after the second cycle in percentage from the check strain; season;2015

\begin{tabular}{|c|c|c|c|c|c|c|c|c|c|c|c|c|}
\hline Ser & SCY/P;g & LY/P;g & lint\% & NB/P & BW & SI;g & LI;g & NS/B & DFF & MIC & PI & UHM \\
\hline 334 & $22.92 * *$ & $27.19 * *$ & $3.46 * *$ & $\mid 15.14$ & $5.56^{*}$ & -2.38 & $8.59 * *$ & 3.51 & -0.98 & $-10.26^{* *}$ & 3.16 & $4.08^{*}$ \\
\hline 54 & 7.60 & 9.14 & $1.44^{*}$ & \begin{tabular}{|l|}
6.31 \\
\end{tabular} & 0.00 & -5.44 & $8.49 * *$ & 3.51 & $\mid-4.90 * *$ & $-9.40^{* *}$ & 1.40 & $4.53^{*}$ \\
\hline 31 & \begin{tabular}{|l|}
$26.37^{* * *}$ \\
\end{tabular} & $26.25^{* *}$ & -0.09 & \begin{tabular}{|l|}
12.03 \\
\end{tabular} & $11.56^{* *}$ & $3.74 * *$ & -3.49 & $7.02 *$ & -0.98 & -1.71 & 3.16 & $6.29 * *$ \\
\hline 700 & 4.95 & 5.19 & 0.24 & 2.48 & 1.11 & 0.68 & 0.00 & 0.00 & 0.49 & -4.27 & 4.21 & $4.42 *$ \\
\hline 699 & 13.12 & 13.93 & 0.73 & \begin{tabular}{|l|}
11.87 \\
\end{tabular} & 0.00 & -1.70 & $3.18^{*}$ & 0.00 & $\mid-1.96 * *$ & 4.27 & 3.51 & $3.53^{*}$ \\
\hline 3 & $16.53^{*}$ & $18.16^{*}$ & $1.38^{*}$ & \begin{tabular}{|l|}
10.63 \\
\end{tabular} & 4.11 & $3.40^{*}$ & -0.83 & -1.75 & -0.49 & 3.42 & 1.75 & 0.00 \\
\hline 105 & 10.36 & 14.31 & $3.62 * *$ & -4.79 & $14.44 * *$ & -1.36 & $7.76 * *$ & $12.28^{* *}$ & $\mid-5.39 * *$ & -4.27 & 1.05 & 2.98 \\
\hline 354 & -11.92 & -10.70 & $1.41^{*}$ & -7.92 & -5.56 & -3.40 & $6.20 * *$ & -3.51 & $\mid-4.90 * *$ & 0.85 & 2.81 & 0.11 \\
\hline 362 & 4.34 & 3.68 & -0.64 & -2.69 & $5.78^{*}$ & 2.72 & -3.39 & 3.51 & -0.98 & -2.56 & 0.00 & $4.30^{*}$ \\
\hline 48 & 8.66 & 8.29 & -0.23 & -1.66 & $9.33 * *$ & $3.06^{*}$ & -3.02 & $7.02 *$ & 1.96 & 2.56 & \begin{tabular}{|c|}
6.67 \\
\end{tabular} & $5.52 * *$ \\
\hline Mean & 10.29 & $11.54 *$ & $1.13^{*}$ & 4.14 & $4.63^{*}$ & -0.07 & $2.35^{*}$ & 3.16 & $\mid-1.81 * *$ & -2.14 & 2.77 & $3.58^{* *}$ \\
\hline $\begin{array}{l}\text { RLSD } \\
0.05 \% \text { for } \\
\text { mean } 1\end{array}$ & 10.84 & 10.97 & 1.00 & 11.98 & 4.08 & 2.07 & 1.83 & 5.08 & 0.93 & 4.72 & - & 2.51 \\
\hline $\begin{array}{l}\text { RLSD } \\
0.01 \% \text { for } \\
\text { mean }\end{array}$ & 14.92 & 13.97 & 1.36 & 17.30 & 5.53 & 2.77 & 2.45 & 7.00 & 1.24 & 6.50 & - & 3.46 \\
\hline $\begin{array}{l}\text { RLSD } \\
0.05 \% \text { for } \\
\text { families } 2\end{array}$ & 14.61 & 14.79 & 1.35 & 16.15 & $5 * .50$ & 2.79 & 2.46 & 6.85 & 1.26 & 6.37 & - & 3.39 \\
\hline $\begin{array}{l}\text { RLSD } \\
0.01 \% \text { for } \\
\text { families }\end{array}$ & 20.12 & 18.84 & 1.83 & 23.33 & 7.46 & 3.74 & 3.30 & 9.43 & 1.68 & 8.76 & - & 4.67 \\
\hline & & & & & & & & & & & & \\
\hline
\end{tabular}

**and**; significant at 0.05 and 0.01 levels of probability; respectively.- Insignificant genotypes mean squares 
Table 7. Means of the studied traits after two cycles of selection for Lint \%; season 2015.

\begin{tabular}{|c|c|c|c|c|c|c|c|c|c|c|c|c|}
\hline Ser & SCY/P;g & LY/P;g & lint\% & NB/P & BW & SI;g & LI;g & NS/B & DFF & MIC & PI & UHM \\
\hline 226 & 105.07 & 42.03 & 40.00 & 29.16 & 3.60 & 10.13 & 6.59 & 21.00 & 69.67 & 3.63 & 10.17 & 30.90 \\
\hline 193 & 91.37 & 36.50 & 39.94 & 28.85 & 3.17 & 9.83 & 6.76 & \begin{tabular}{|l|l|}
19.33 \\
\end{tabular} & \begin{tabular}{|l|}
68.67 \\
\end{tabular} & 3.60 & 9.97 & 31.83 \\
\hline 633 & 105.33 & 42.87 & 40.69 & 35.50 & 2.97 & 9.97 & \begin{tabular}{|l|}
6.89 \\
\end{tabular} & \begin{tabular}{|l|l|}
17.67 \\
\end{tabular} & \begin{tabular}{|l|}
69.67 \\
\end{tabular} & 3.63 & 10.03 & 30.10 \\
\hline 435 & 88.90 & 35.63 & 40.10 & 30.01 & 2.97 & 10.57 & 6.34 & $\mid 16.67$ & \begin{tabular}{|c|}
70.33 \\
\end{tabular} & 3.60 & 9.97 & 30.57 \\
\hline 209 & 95.83 & 37.87 & 39.50 & 30.17 & \begin{tabular}{|l|l|}
3.17 \\
\end{tabular} & \begin{tabular}{|l|}
10.17 \\
\end{tabular} & 6.42 & 19.00 & \begin{tabular}{|l|}
67.33 \\
\end{tabular} & 3.80 & 9.50 & 31.50 \\
\hline 847 & 99.37 & 39.43 & 39.67 & 34.01 & 2.92 & \begin{tabular}{|l|}
10.10 \\
\end{tabular} & 6.51 & 17.33 & \begin{tabular}{|l|}
68.67 \\
\end{tabular} & \begin{tabular}{|l|}
4.23 \\
\end{tabular} & 10.10 & 31.03 \\
\hline 712 & 106.73 & 42.83 & 40.13 & 35.91 & \begin{tabular}{|l|}
2.98 \\
\end{tabular} & 10.17 & 6.59 & \begin{tabular}{|l|}
18.33 \\
\end{tabular} & \begin{tabular}{|l|}
69.00 \\
\end{tabular} & 4.03 & 9.53 & 32.40 \\
\hline 836 & 106.20 & 41.43 & 39.03 & 37.01 & \begin{tabular}{|l|}
2.88 \\
\end{tabular} & 9.40 & \begin{tabular}{|l|}
6.81 \\
\end{tabular} & \begin{tabular}{|l|l|}
18.33 \\
\end{tabular} & \begin{tabular}{|l|}
68.33 \\
\end{tabular} & 3.60 & 9.93 & 31.13 \\
\hline 590 & 107.67 & 43.20 & 40.14 & 36.01 & 2.99 & \begin{tabular}{|l|}
10.03 \\
\end{tabular} & 6.68 & \begin{tabular}{|l|}
17.67 \\
\end{tabular} & \begin{tabular}{|l|}
68.67 \\
\end{tabular} & 4.03 & 10.27 & 30.67 \\
\hline 624 & 93.23 & 37.13 & 39.83 & 31.79 & \begin{tabular}{|l|}
2.93 \\
\end{tabular} & 10.70 & 6.19 & \begin{tabular}{|l|l|}
16.33 \\
\end{tabular} & 67.67 & 4.10 & 10.53 & 30.60 \\
\hline Mean & 99.97 & 39.89 & 39.90 & 32.84 & 3.06 & 10.11 & \begin{tabular}{|l|}
6.58 \\
\end{tabular} & \begin{tabular}{|l|l|}
18.17 \\
\end{tabular} & \begin{tabular}{|l|}
68.80 \\
\end{tabular} & \begin{tabular}{|l|}
3.83 \\
\end{tabular} & 10.00 & 31.07 \\
\hline Check & 91.85 & 35.46 & 38.60 & 31.00 & 3.00 & 9.80 & 6.40 & \begin{tabular}{|l|l|}
19.00 \\
\end{tabular} & \begin{tabular}{|l|}
68.00 \\
\end{tabular} & 3.90 & 9.50 & 30.20 \\
\hline $\begin{array}{l}\text { RLSD } 0.05 \\
\text { for mean } 1\end{array}$ & 13.65 & 5.40 & 0.64 & 4.69 & 0.12 & 0.24 & 0.17 & 0.62 & 0.73 & 0.23 & 0.53 & 0.68 \\
\hline $\begin{array}{l}\text { RLSD } 0.01 \\
\text { for mean }\end{array}$ & 20.05 & 7.93 & 0.88 & 6.77 & 0.16 & 0.33 & 0.23 & 0.88 & 1.00 & 0.29 & 0.77 & 0.86 \\
\hline $\begin{array}{l}\text { RLSD } 0.05 \\
\text { for families2 }\end{array}$ & 18.41 & 7.28 & 0.86 & 6.32 & 0.16 & 0.33 & 0.23 & 0.83 & 0.99 & 0.30 & 0.72 & 0.91 \\
\hline $\begin{array}{l}\text { RLSD } 0.01 \\
\text { for families }\end{array}$ & 27.04 & 10.69 & 1.18 & 9.13 & 0.21 & 0.45 & 0.32 & 1.18 & 1.34 & 0.39 & 1.03 & 1.16 \\
\hline \multicolumn{13}{|c|}{ 1- to compare mean with } \\
\hline
\end{tabular}

Table 8. Observed genetic gain from selection for Lint \% after the second cycle in percentage from the check strain; season 2015.

\begin{tabular}{|c|c|c|c|c|c|c|c|c|c|c|c|c|}
\hline Ser & SCY/P;g & LY/P;g & lint $\%$ & $\mathrm{NB} / \mathrm{P}$ & BW & SI;g & LI;g & NS/B & DFF & MIC & PI & UHM \\
\hline 226 & 14.39 & 18.54 & $3.63 * *$ & -5.93 & 20.00 ** & $3.40^{*}$ & 2.92 & $10.53 * *$ & $2.45 * *$ & -6.84 & 7.02 & 2.32 \\
\hline 193 & -0.53 & 2.93 & $3.46^{* *}$ & -6.95 & $5.56^{*}$ & 0.34 & $5.68 * *$ & 1.75 & 0.98 & -7.69 & 4.91 & $5.41 * *$ \\
\hline 633 & 14.68 & $20.89^{*}$ & $5.42 * *$ & 14.51 & -1.11 & 1.70 & $7.60 * *$ & -7.02 & $2.45 * *$ & -6.84 & 5.61 & -0.33 \\
\hline 435 & -3.21 & 0.49 & $3.89 * *$ & -3.20 & -1.11 & $7.82 * *$ & -0.94 & -12.28 & $3.43 * *$ & -7.69 & 4.91 & 1.21 \\
\hline 209 & 4.34 & 6.79 & $2.33^{*}$ & -2.69 & $5.78^{*}$ & $3.74 *$ & 0.36 & 0.00 & -0.98 & -2.56 & 0.00 & $4.30 * *$ \\
\hline 847 & 8.18 & 11.21 & $2.77 *$ & 9.71 & -2.67 & 3.06 & 1.72 & -8.77 & 0.98 & $8.55^{*}$ & 6.32 & 2.76 \\
\hline 712 & 16.20 & \begin{tabular}{|l|}
$20.79 *$ \\
\end{tabular} & $3.97 * *$ & 15.85 & -0.67 & $3.74 *$ & 3.02 & -3.51 & $1.47 *$ & 3.42 & 0.35 & $7.28 * *$ \\
\hline 836 & 15.62 & 16.85 & 1.13 & 19.40 & -4.00 & -4.08 & $6.46^{* *}$ & -3.51 & 0.49 & -7.69 & 4.56 & $3.09^{*}$ \\
\hline 590 & 17.22 & $21.83^{*}$ & $3.98 * *$ & 16.16 & -0.22 & 2.38 & $4.43^{*}$ & -7.02 & 0.98 & 3.42 & $8.07 *$ & 1.55 \\
\hline 624 & 1.51 & 4.72 & $3.19 * *$ & 2.56 & -2.22 & $9.18^{* *}$ & -3.28 & -14.04 & -0.49 & 5.13 & $10.88 * *$ & 1.32 \\
\hline Mean & 8.84 & 12.50 & $3.38 * *$ & 5.94 & 1.93 & $3.13^{*}$ & $2.80 *$ & -4.39 & $1.18^{*}$ & -1.88 & 5.26 & $2.89 * *$ \\
\hline $\begin{array}{l}\text { RLSD } \\
0.05 \text { for } \\
\text { mean } 1\end{array}$ & - & 15.23 & 1.65 & 15.13 & 3.90 & 2.50 & 2.70 & 3.25 & 1.08 & 5.78 & 5.58 & 2.24 \\
\hline $\begin{array}{l}\text { RLSD } \\
0.01 \text { for } \\
\text { mean }\end{array}$ & - & 22.36 & 2.27 & 21.85 & 5.23 & 3.39 & 3.67 & 4.62 & 1.46 & 7.37 & 8.07 & 2.85 \\
\hline $\begin{array}{l}\text { RLSD } \\
0.05 \text { for } \\
\text { families } 2\end{array}$ & - & 20.53 & 2.23 & 20.40 & 5.25 & 3.37 & 3.64 & 4.39 & 1.46 & 7.80 & 7.53 & 3.02 \\
\hline $\begin{array}{l}\text { RLSD } \\
0.01 \text { for } \\
\text { families }\end{array}$ & - & 30.15 & 3.07 & 29.47 & 7.05 & 4.57 & 4.94 & 6.23 & 1.97 & 9.94 & 10.88 & 3.85 \\
\hline
\end{tabular}

1- to compare mean with the check

2- to compare a family with the check

*and**; significant at 0.05 and 0.01 levels of probability; respectively. - insignificant genotypes mean squares 
Table 9. Means of the studied traits after two cycle of selection for DFF; season 2015

\begin{tabular}{|c|c|c|c|c|c|c|c|c|c|c|c|c|}
\hline Ser & SCY/P;g & LY/P;g & lint $\%$ & NB/P & BW & SI;g & LI;g & NS/B & DFF & MIC & PI & UHM \\
\hline 529 & 106.33 & 41.67 & 39.21 & 32.23 & 3.32 & 10.43 & 6.18 & 19.67 & 64.33 & 4.17 & 11.03 & 31.13 \\
\hline 54 & 98.83 & 38.70 & 39.15 & 32.96 & 3.00 & 9.27 & 6.94 & 19.67 & 64.67 & 3.53 & 9.63 & 31.57 \\
\hline 341 & 96.20 & 37.43 & 38.91 & 30.64 & 3.16 & 10.13 & 6.29 & 19.33 & 66.33 & 3.97 & 9.97 & 31.67 \\
\hline 39 & 105.10 & 40.63 & 38.67 & 32.16 & 3.27 & 10.03 & 6.29 & 20.00 & 64.33 & 3.70 & 9.87 & 30.13 \\
\hline 83 & 103.17 & 40.17 & 38.93 & 30.64 & 3.37 & 10.27 & 6.21 & 20.00 & 64.33 & 3.83 & 9.77 & 31.37 \\
\hline 73 & 115.87 & 45.90 & 39.63 & 37.30 & 3.11 & 10.33 & 6.36 & 18.33 & 64.67 & 4.03 & 9.83 & 30.50 \\
\hline 75 & 113.17 & 43.33 & 38.30 & 37.76 & 3.01 & 9.63 & 6.45 & 19.33 & 65.00 & 3.90 & 9.57 & 30.30 \\
\hline 156 & 108.93 & 41.37 & 37.99 & 36.96 & 2.95 & 9.50 & 6.46 & 19.33 & 65.67 & 3.83 & 10.47 & 30.87 \\
\hline 335 & 110.63 & 42.40 & 38.33 & 36.79 & 3.01 & 9.93 & 6.26 & 19.00 & 64.67 & 4.00 & 10.77 & 31.50 \\
\hline 358 & 102.00 & 39.10 & 38.35 & 33.02 & 3.09 & 9.80 & 6.35 & 19.33 & 64.33 & 3.83 & 9.50 & 31.80 \\
\hline Mean & 106.02 & 41.07 & 38.75 & 34.05 & 3.13 & 9.93 & 6.38 & 19.40 & 64.83 & 3.88 & 10.04 & 31.08 \\
\hline Check & 91.85 & 35.46 & 38.60 & 31.00 & 3.00 & 9.80 & 6.40 & 19.00 & 68.00 & 3.90 & 9.50 & 30.20 \\
\hline $\begin{array}{l}\text { RLSD } 0.05 \text { for } \\
\text { mean } 1\end{array}$ & 9.37 & 3.14 & 0.52 & 3.85 & 0.21 & 0.30 & 0.33 & - & 0.69 & 0.25 & 0.52 & 0.77 \\
\hline $\begin{array}{l}\text { RLSD } 0.01 \text { for } \\
\text { mean }\end{array}$ & 13.26 & 4.32 & 0.72 & 5.45 & 0.30 & 0.41 & 0.48 & - & 0.93 & 0.37 & 0.66 & 1.09 \\
\hline $\begin{array}{l}\text { RLSD } 0.05 \text { for } \\
\text { families } 2\end{array}$ & 12.63 & 4.23 & 0.70 & 5.19 & 0.28 & 0.40 & 0.44 & - & 0.93 & 0.34 & 0.70 & 1.04 \\
\hline $\begin{array}{l}\text { RLSD } 0.01 \text { for } \\
\text { families }\end{array}$ & 17.88 & 5.83 & 0.97 & 7.35 & 0.41 & 0.55 & 0.64 & - & 1.25 & 0.50 & 0.89 & 1.47 \\
\hline
\end{tabular}

-Insignificant genotypes mean squares

Table 10. Observed genetic gain from selection for DFF after the second cycle in percentage from the check strain; season 2015

\begin{tabular}{|c|c|c|c|c|c|c|c|c|c|c|c|c|}
\hline Ser & SCY/P;g & LY/P;g & lint $\%$ & NB/P & BW & SI;g & LI;g & NS/B & DFF & MIC & PI & \begin{tabular}{|l|} 
UHM \\
\end{tabular} \\
\hline 529 & $15.77 *$ & $17.50 * *$ & 1.58 & 3.95 & $10.67 *$ & $6.46^{* *}$ & -3.39 & 3.51 & $-5.39 * *$ & 6.84 & $16.14 * *$ & 3.09 \\
\hline 54 & 7.60 & 9.14 & 1.44 & 6.31 & 0.00 & -5.44 & $8.49^{*}$ & 3.51 & $-4.90 * *$ & -9.40 & 1.40 & $4.53^{*}$ \\
\hline 341 & 4.74 & 5.56 & 0.81 & -1.15 & 5.33 & 3.40 & -1.77 & 1.75 & $-2.45 * *$ & 1.71 & 4.91 & $4.86^{*}$ \\
\hline 39 & $14.43^{*}$ & $14.59 *$ & 0.19 & 3.76 & 8.89 & 2.38 & -1.77 & 5.26 & $-5.39 * *$ & -5.13 & 3.86 & -0.22 \\
\hline 83 & 12.32 & $13.27^{*}$ & 0.87 & -1.15 & $12.22 *$ & $4.76^{*}$ & -2.92 & 5.26 & $-5.39 * *$ & -1.71 & 2.81 & $3.86^{*}$ \\
\hline 73 & $26.15 * *$ & $29.44 * *$ & $2.66^{* *}$ & $20.33^{*}$ & 3.56 & $5.44^{*}$ & -0.68 & -3.51 & $-4.90 * *$ & 3.42 & 3.51 & 0.99 \\
\hline 75 & $23.21 * *$ & $22.20 * *$ & -0.77 & $21.82 *$ & 0.22 & -1.70 & \begin{tabular}{|l|}
0.78 \\
\end{tabular} & 1.75 & $-4.41 * *$ & 0.00 & 0.70 & 0.33 \\
\hline 156 & $18.60 *$ & $16.66^{* *}$ & -1.58 & $19.22 *$ & -1.56 & -3.06 & 0.99 & 1.75 & $-3.43 * *$ & -1.71 & $10.18 * *$ & 2.21 \\
\hline 335 & $20.45 * *$ & $19.57 * *$ & -0.70 & $18.68^{*}$ & 0.44 & 1.36 & -2.14 & 0.00 & $-4.90 * *$ & 2.56 & $13.33 * *$ & $4.30 *$ \\
\hline 358 & 11.05 & 10.27 & -0.65 & 6.53 & 2.89 & 0.00 & -0.78 & 1.75 & $-5.39 * *$ & -1.71 & 0.00 & $5.30 * *$ \\
\hline Mean & $15.43 * *$ & $15.82 * *$ & 0.38 & 9.83 & 4.27 & 1.36 & -0.32 & 2.11 & $-4.66^{* *}$ & -0.51 & 5.68 & 2.92* \\
\hline $\begin{array}{l}\text { RLSD } \\
0.05 \% \text { for } \\
\text { mean } 1 \\
\end{array}$ & 10.20 & 8.85 & 1.35 & 12.42 & 6.94 & 3.06 & 5.14 & - & 1.02 & 6.53 & 5.48 & 2.56 \\
\hline $\begin{array}{l}\text { RLSD } \\
0.01 \% \text { for } \\
\text { mean }\end{array}$ & 14.43 & 12.18 & 1.86 & 17.57 & 10.02 & 4.15 & 7.43 & - & 1.36 & 9.44 & 6.99 & 3.62 \\
\hline $\begin{array}{l}\text { RLSD } \\
0.05 \% \text { for } \\
\text { families } 2\end{array}$ & 13.76 & 11.93 & 1.82 & 16.75 & 9.35 & 4.12 & 6.93 & - & 1.37 & 8.81 & 7.39 & 3.45 \\
\hline $\begin{array}{l}\text { RLSD } \\
0.01 \% \text { for } \\
\text { families } \\
\end{array}$ & 19.46 & 16.43 & 2.50 & 23.70 & 13.51 & 5.59 & 10.01 & - & 1.84 & 12.73 & 9.42 & 4.88 \\
\hline to & 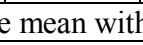 & the che & & & & & & & & & & \\
\hline
\end{tabular}

- Insignificant genotypes mean squares. *and**; significant at 0.05 and 0.01 levels of probability; respectively 
Table 11. The observed genetic gain of the three superior families in yield from each selection procedure with favorable or no effect on fiber properties; season 2015.

\begin{tabular}{|c|c|c|c|c|c|c|c|c|c|c|c|c|c|}
\hline Sel.for & Ser. & Scy/P;g & Ly/P;g & Lint $\%$ & $\mathrm{NB} / \mathrm{P}$ & Bw;g & SI;g & LI;g & NS/B & DFF & MIC & PI & UHM \\
\hline \multirow{4}{*}{$\mathrm{LY} / \mathrm{P}$} & 334 & $22.92 * *$ & $27.19 * *$ & $3.46^{* *}$ & $15.14^{*}$ & 5.56 & -2.38 & $8.59 * *$ & 3.51 & -0.98 & \begin{tabular}{|l|}
$-10.26^{*}$ \\
\end{tabular} & 3.16 & $4.08^{*}$ \\
\hline & 31 & $26.37 * *$ & $26.25 * *$ & -0.09 & 12.03 & $11.56 * *$ & 3.74 & -3.49 & $7.02 * *$ & -0.98 & -1.71 & 3.16 & $6.29 * *$ \\
\hline & 361 & $22.34 * *$ & $22.86^{* *}$ & 0.38 & $17.51^{*}$ & 3.11 & 0.00 & 0.42 & 1.75 & -0.98 & 0.85 & 2.11 & $4.75^{* *}$ \\
\hline & Mean & $19.75 * *$ & 20.30 ** & 0.44 & $14.01 *$ & 3.92 & 1.60 & -0.38 & 0.70 & 0.15 & -2.91 & 1.72 & 0.97 \\
\hline \multirow{4}{*}{$\begin{array}{c}\mathrm{LY} / \mathrm{P} \\
\text { re- } \\
\text { stricted } \\
\text { By } \\
\text { DFF }\end{array}$} & 334 & $22.92 * *$ & $27.19 * *$ & $3.46^{* *}$ & 15.14 & $5.56^{*}$ & -2.38 & $8.59 * *$ & 3.51 & -0.98 & $-10.26^{* *}$ & 3.16 & $4.08^{*}$ \\
\hline & 31 & $26.37 * *$ & $26.25 * *$ & -0.09 & 12.03 & $11.56^{* *}$ & $3.74 * *$ & -3.49 & $7.02 *$ & -0.98 & -1.71 & 3.16 & $6.29 * *$ \\
\hline & 3 & $16.53 *$ & $18.16^{*}$ & $1.38^{*}$ & 10.63 & 4.11 & $3.40 *$ & -0.83 & -1.75 & -0.49 & 3.42 & 1.75 & 0.00 \\
\hline & Mean & 1 & 1 & $1.13^{*}$ & 4.14 & 4 & $-c$ & 35 & 6 & $-1.81^{* *}$ & -2.14 & 2.77 & $*$ \\
\hline \multirow{4}{*}{ Lint $\%$} & 633 & 14.68 & $20.89^{*}$ & $5.42 * *$ & 14.51 & -1.11 & 1.70 & $7.60 * *$ & -7.02 & $2.45^{* *}$ & -6.84 & 5.61 & -0.33 \\
\hline & 712 & 16.20 & $20.79 *$ & $3.97 * *$ & 15.85 & -0.67 & $3.74 *$ & 3.02 & -3.51 & $1.47^{*}$ & 3.42 & 0.35 & $7.28 * *$ \\
\hline & 590 & 17.22 & $21.83 *$ & $3.98^{* *}$ & 16.16 & -0.22 & 2.38 & $4.43 *$ & -7.02 & 0.98 & 3.42 & $8.07 *$ & 1.55 \\
\hline & Mean & 8.84 & 12.50 & $3.38 * *$ & 5.94 & 1.93 & $3.13^{*}$ & $2.80^{*}$ & -4.39 & $1.18^{*}$ & -1.88 & 5.26 & $2.89^{* *}$ \\
\hline \multirow{4}{*}{ DFF } & 73 & $26.15 * *$ & $29.44 * *$ & $2.66^{* *}$ & $20.33^{*}$ & 3.56 & $5.44^{*}$ & -0.68 & -3.51 & $-4.90 * *$ & 3.42 & 3.51 & 0.99 \\
\hline & 156 & $18.60 *$ & $16.66^{* *}$ & -1.58 & $19.22 *$ & -1.56 & -3.06 & 0.99 & 1.75 & $-3.43 * *$ & -1.71 & $10.18^{* *}$ & 2.21 \\
\hline & 335 & $20.45 * *$ & $19.57 * *$ & -0.70 & $18.68^{*}$ & 0.44 & 1.36 & -2.14 & 0.00 & $-4.90 * *$ & 2.56 & $13.33^{* *}$ & $4.30 *$ \\
\hline & Mean & $15.43 * *$ & $15.82 * *$ & 0.38 & 9.83 & 4.27 & 1.36 & -0.32 & 2.11 & $-4.66 * *$ & -0.51 & 5.68 & $2.92 *$ \\
\hline
\end{tabular}

*and**; significant at 0.05 and 0.01 levels of probability; respectively. Mean $;$; mean of the ten selected families.

\section{References}

Abdel-Zaher, G.H., M.A. Nageb and A.A. Mohamed. 2007. Selection efficiency for lint percentage and the extent of its influence on the other traits in Giza 83 Egyptian cotton variety. Egypt. J. Plant breed., 11:479-486.

Abou EL-Yazied, M.A., Y.A.M. Solimanand Y.M. EL- Mansy.2014. Effectiveness of recurrent selection for improvement of some economic characters in Egyptian cotton. Egypt J. Agric. Res., 92 (1):2014 135-151.

Abo El-Zahab, A.A., and M.A. ElKilany. 1979. Correlated response to several selection procedures for increased lint yield in segregating generations of Egyptian cotton (GossypiumbarbadenseL) Beitragetrop.Landwirtsch. Veterinarmed. 17. Jg. (1979) 165-172.

Ahmed, H. M., M. M. Kandhro, S. Laghari and S. Abro. 2006. Heritability and genetic advance as selection indicators for improvement in cotton (Gossypiumhirsutum L.). J. Bio. Sci., 6: 96-99.

Ahuja, S. L., D. Monga, O. P. Tuteja, S. K. Verma, L. S. Dhayal, and D. Yagya.2004. Association and path analysis in the selections made from colorlinted (Gossypiumhirsutum L.). cotton germplasm. J. Cott. Res. Rev. 18 (2): 137-140.

Al-Jibouri, H.A.; P.A. Miller and H.F. Robinson. 1958. Genotypic and environmental variances and covariances in an Upland cotton cross of interspecific origin. Agron. J., 50: 633-636.

Basbag, S. and O. Gencer. 2004. Investigations on the heritability of seed cotton yield, yield components and technological characters in cotton (Gossypiumhirsutum L.). Pakistan J. Biol. Sci. 7 (8): 1390-1393.

Burton, G.W. (1952). Quantitative inheritance in grass-proc. 6th Int. GrassldCongr. 1: 227-283.

El-Defrawy, M.M. and T.M. ElAmeen.2004. Selection for earliness in Egyptian cotton (Gos- 
sypiumBarbadense L.) Assiut J. of Agric. Sci., 35: 95-108.

EL-Harony, H.A. 1998. Direct and indirect selection for some yield and some fiber properties in Giza 77 Egyptian cotton variety. Ann. Agri. Sci. Moshtohor. 36: 713718.

El-Kilany, M.A. 1976. Comparative studies of selection techniques in developing and maintaining Egyptian cotton. Ph.D. Thesis, Cairo Univ., Egypt.

El-Lawendey, M.M. and M.A.A. ElDahan. 2012. Comparison between direct and indirect selection and two indices in segregating population of cotton (GossypiumbarbadenseL.). J. Agric. Res. Kafer El-Sheikh Univ., 38(1):37-53.

El Rawi, K., and A.M. Khalafalla. 1980. Design and Analysis of Agricultural Experiments, El Mousel Univ., Iraq.

Gomaa, M.A.M. and A.M.A. Shaheen. 1995. Heterosis, inbreeding depression, heritability and type of gene action in two intrabarbadense cotton crosses. Annals Agric. Sci., Ain Shams Univ., Cairo, 40: 165-176.

Gomaa, M. A. M., A. M. A. Shaheen, S. A. M. Khattab.1999. Gene action and selection indices in two cotton (Gossypiumbarbadense crosses. Ann. Agric. Sci. Cairo, 44: 293-308.

Gooda, B.M.R. 2007. Improvement of some economic characters in crosses of Egyptian cotton (Gossypiumbarbadense 1.) Ph. D. Thesis, Kafr El-Sheikh Univ., Egypt.

Hassaballa, E. A., E. E. Mahdy, A. A. Mohamed and A. M. Aly. 2012. Selection for earliness index in two segregating populations of Egyptian cotton ( $G$. barbadense L.) under late planting. Assiut J. Agric. Sci., 43:1-17.
Khan, N. U.,G. Hassan, I. A. Khan and W. Ahmad. 2009. Genetic variability and heritability in upland cotton. Pak. J. Bot., 41: 1695-1705.

Lioyd M. O., and B.C. Bridges. 1995. Breeding cotton for conventional and late planted production system. Crop Sci., 35: $132-136$.

Mahdy, E.E. (1983a). Selections index in cotton ( $G$. barbadense L.). Assiut J. Agric. Sci., 14: 267-282.

Mahdy, E.E. 1983b. Relative effectiveness of pedigree line and recurrent selection for improving lint yield in cotton ( $G$. barbadense L.). Assiut J. of Agric. Sci., 14: 315-325.

Mahdy, E.E., A.A. Ismail, H.Y. Awad, and A.A. Mohamed. 2001a. The relative merits of breeding and modified recurrent selection in improving seed cotton yield in two segregating populations of Egyptian cotton ( $G$ barbadense $L$.). The 2nd Plant Breed. Conf. Oct. 2, 6179.

Mahdy, E.E., A.A. Ismail, H.Y. Awad, and A.A. Mohamed. 2001b. The relative merits of breeding and modified recurrent selection in improving earliness in two segregating populations of Egyptian cotton (G. barbadense L.). The 2nd Plant Breed. Conf. Fac. Agric. Assiut Univ. Oct. 2, 2001: 80-101.

Mahdy, E.E., A.A. Mohamed, M.Z. Elhifny, and H. Mahrous.2006. Pedigree selection for earliness index in two populations of Egyptian cotton. MiniaJ.of Agric. Res. \&Devolp., 26: 485-506.

Mahdy, E.E., A.A. Mohamed, M.Z. Elhifny, and H. Mahrous.2007. Selection for seed cotton yield in early and late sowing dates of Egyptian cotton. MiniaJ.of Agric. Res. \&Devolp., 27: 1-22.

Mahdy, E.E.; G.M.K. Hemaida; F.M.F. Abd El-Motagally and A. Mostafa.2009a. Response to selection 
for yield under late sowing date in two populations of Egyptian cotton. Assiut J. Agric. Sci., 40(Special Issue):1-25.

Mahdy, E. E., G.M.K. Hemaida; F.M.F.Abd El-Motagally and A. Mostafa. 2009b. Pedigree selection for lint yield, lint percentage and earliness index in late planting in two populations of Egyption cotton Minia J. of Agric. Res.\& develop., 29:233-258.

Mahdy, E. E.; E. A. Hassaballa; A. A. Mohamed; and A. M. Aly. 2013a.Pedigree selection for lint yield at late planting Egyptian cotton ( $G$. barbadense L.). Egypt . J. of Appl. Sci., 28 (4) 239-254.

Mahdy, E. E.; E. A. Hassaballa; A. A. Mohamed; and A. M. Aly. 2013b.Pedigree selection for number of bolls/ plant in two populations of Egyptian cotton under late planting conditions. Egypt . J. of Appl. Sci., 28 (4) 255-270.

Mahrous, H. 2004. Pedigree selection for earliness and yield under early and late plantings in two segregating populations of Egyptian cotton ( $G$. barbadense L.). M. Sc. Thesis, Assiut Univ., Egypt.

Manning, H.L. 1956. Yield improvement from a selection index technique with cotton. Heredity, 10: 303-322.

Mustafa, F.S., M.M. Awaad, and S.I.S. Abou-Zahra. 1995. Evaluation of some strains of long stable cotton hybrids at different locations in Egypt in 1993 season: lint cotton yield and fiber properties. Proceedings Beltwide Cotton Conferences, San Antonio, TX, USA, January 47, (1): 586-587.

Naveed, M., F., M. Azhar and A. Ali. 2004. Estimates of Heritabilities and Correlations Among Seed CottonYield and its Components in Gossypiumhirsutum L.. PakistanJ.of Biol.. Sci. 6 (4): 712-714.

Okasha, A.A. 1998. Expected and actual gains for yield, yield components and fiber quality in Giza 45 cotton cultivar. Ann. Agric. Sci. Moshtohor, 36: 1373-1380.

Singh, B., G.S. Chahal, and T.H. Singh. 1995. Efficiency of different selection criteria for the improvement of seed cotton yield in early segregating generations of (Gossypiumhirsutum L.). Crop Improv. 22: 6164. (C.F. Plant breeding Abst.67: 1868, 1997).

Soomro, Z.A., M.B. Kumbhar, A.S. Larik, M. Imran and S.A. Brohi. 2010. Heritability and selection response in segreganting generations of Upland cotton. Pakistan J. Agric. Res., 23:25-30.

Srour, M.S.M., M. A. Hager, E. I. Zaazaa and E. F. EL-Hashash. 2010.Genetic analysis for some yield and fiber quality traits using F2 and F3 populations in Cotton. J. Plant Prod. Mansoura Univ., Vol. 1 (12): 1593-1604.

Tang, F.Y., C. Jin, H.W. Xin, M.W. Cheng and X.W. Jun. 2009. Genetic variation and selection indices of quantitative traits in Upland cotton $(G$. hirsutum L.) lines with high fiber quality. China Cotton Sci., 21: 361-365.

Younis, F.B. 1999. Genetic system and prediction for earliness, Yield and its attributes in two interspecific cotton crosses between $G$. barbadense L. and G. hirsutum L. AlAzhar J. Agric. Res., 29: 1-13. 
كفاءه الاتخاب لصفه واحده لتحسين المحصول و التبكير و المحافظه على صنف القطن

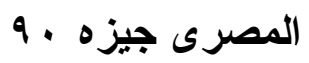

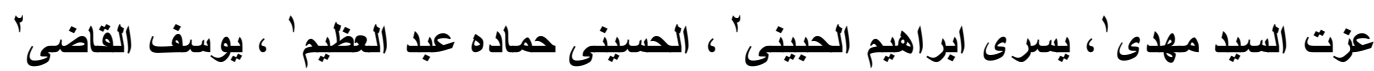

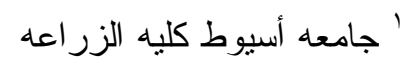

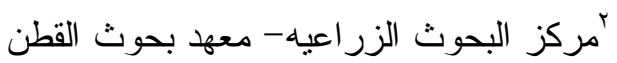

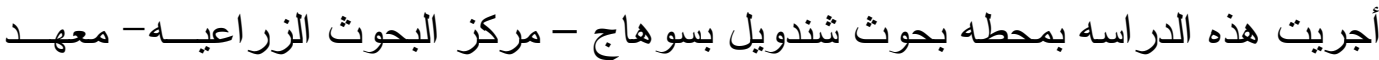

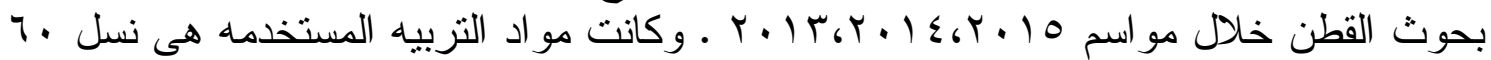

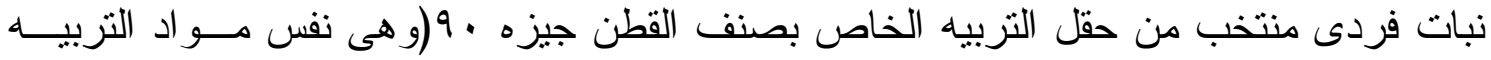

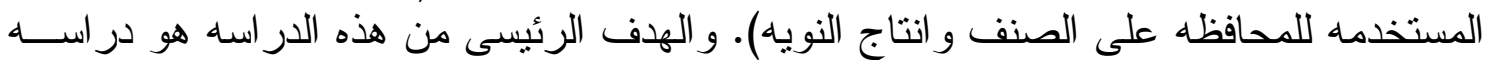

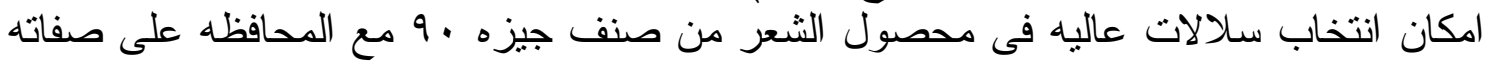

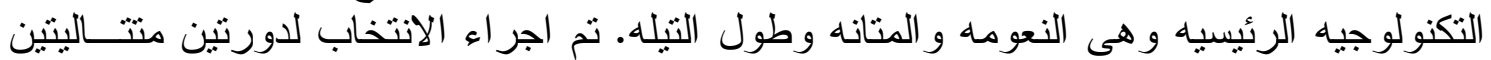

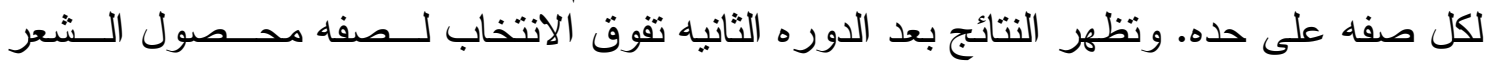

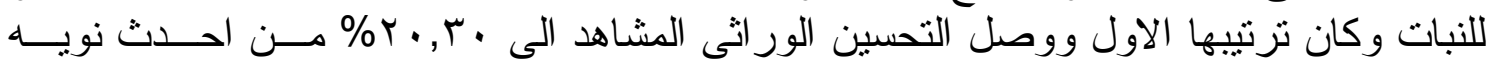

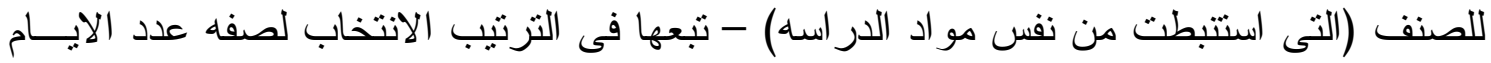

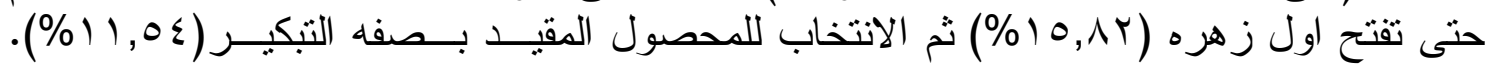

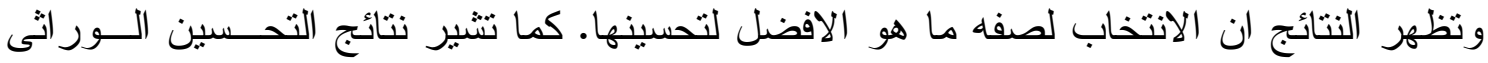

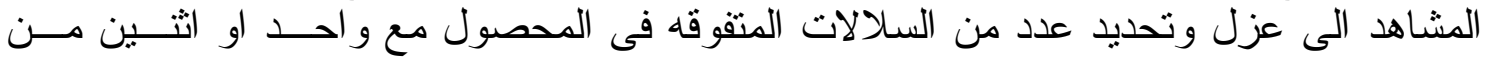

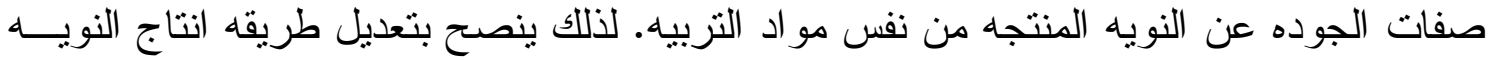
المتبعه حاليا لتسمح بانتخاب سلالات عاليه المحصول ولها نفس صفات الصنف التكنولوجيه. 